\title{
Effects of Agglomeration, Environmental Regulations, and Technology on Pollutant Emissions in China: Integrating Spatial, Social, and Economic Network Analyses
}

\author{
Junsong Wang ${ }^{1,2}\left(\mathbb{D}\right.$, Xinyue $^{3} \mathrm{e}^{3,5}$ and Yehua Dennis Wei ${ }^{4,5, *(\mathbb{C}}$ \\ 1 Institute for Global Innovation \& Development, East China Normal University, Shanghai 200062, China; \\ wjsenjoy@126.com \\ 2 School of Urban and Regional Science, East China Normal University, Shanghai 200062, China \\ 3 Urban Informatics \& Spatial Computing Lab, Department of Informatics, New Jersey Institute of Technology, \\ Newark, NJ 07102, USA; xye@njit.edu \\ 4 Department of Geography, University of Utah, Salt Lake City, UT 84112-9155, USA \\ 5 Key Research Institute of Yellow River Civilization and Sustainable Development \& Collaborative \\ Innovation Center for Yellow River Civilization of Henan Province, Henan University, Kaifeng 475001, China \\ * Correspondence: wei@geog.utah.edu
}

Received: 5 November 2018; Accepted: 5 January 2019; Published: 12 January 2019

\begin{abstract}
Using prefecture-level panel data and social media data, this study investigates how industrial agglomeration, environmental regulations, and technology affect the pollutant intensity and spillover channels of pollutant emissions by integrating social and economic networks into a Spatial Durbin Model. The results show that industrial agglomeration, environmental regulations, and technological inputs facilitate the emissions intensity abatement. The outcomes also confirm that these factors affect the intensity of pollutant emissions in neighboring regions through social, economic, and spatial networks. Agglomeration has a negative spillover effect on the intensity of pollutant emissions in surrounding cities via social and spatial networks, while environmental regulations affect pollutant emissions intensity in related cities through social networks. Technology can effectively lower pollutant emissions through economic networks. These findings highlight the network linkages and spillover channels affecting the intensity of pollutant emissions.
\end{abstract}

Keywords: agglomeration; environmental regulation; pollutant emissions; spatial spillovers; network analysis

\section{Introduction}

Given the rapid urbanization and economic development in China, environmental issues have attracted increasing attention [1,2]. Since environmental issues and local government environmental regulations vary across space, it is necessary to explore the mechanism of pollution emissions by considering the spatial and social relationships among cities [3]. Previous studies [4-6] have examined the mechanisms that influence pollutant emissions from the perspectives of regulations, governance, technology, energy structure, and institutions, and have also explored the relationship between industrial agglomeration and emissions [3,7,8]. Cheng [9] verified the spillover effects across administrative boundaries, but most studies have rarely taken spatial spillover effects into consideration.

Human activities are interdependent across various networks [10-12], and spatial social networks and flows represent the most important features of social and economic life in our increasingly 
interconnected society $[13,14]$. However, the impact of social and economic networks on pollutant emissions has yet to be fully considered [15]. Social media platforms have accumulated a large number of geotagged messages reflecting social concerns about pollution-related issues [13,16,17], and these data can be used to construct spatial social networks [15].

This study examines how industrial agglomeration, environmental regulations and technology affect pollutant emissions intensity using panel data from 285 prefecture-level cities (including four centrally administrated municipalities) during the period 2003-2016, and sheds light on how industrial agglomeration and regulations contribute to the abatement of pollutant emissions. It identifies how social and economic spillover effects occurred in the relationships between environmental regulations, technological inputs and pollutant emissions by introducing social and economic networks into our models.

Spatial Durbin models (SDMs) are applied to the municipal panel data to identify the spatial spillover effects. Social media data from Weibo API and economic data are used to construct a Weibo network and an economic network to represent urban linkages. Then, GIS methods are employed to visualize the social and economic networks, and SDMs are introduced to analyze the spatial, social and economic spillover effects of industry agglomeration, environmental regulations and technology on pollutant emissions.

\section{Literature Review}

Previous studies have identified the determinants of pollution as economic development, environmental regulations, political transparency, R\&D inputs, and ownership $[8,18,19]$. Environmental regulations have received the most attention [20-22], and the effects of industrial agglomeration and technological inputs have also been explored $[3,7,8,23]$. However, insufficient attention has been paid to the spillover channels among various cities.

\subsection{Industrial Agglomeration, Spatial Networks, and Pollutant Emissions Abatement}

Industrial agglomeration leads to increasing returns and higher productivity [24]. Numerous studies have investigated the relationship between manufacturing distribution and pollutant emissions, but the results have been far from conclusive. For example, Lu et al. [8] found a positive relationship between agglomeration and pollution, while Cheng et al. [9] reported an inverted U-shaped relationship. He et al. [23] found a cubic relationship between the density and intensity of industrial $\mathrm{SO}_{2} /$ soot emission. These varied results have arisen from differences in the variables and samples used $[3,7,8,23]$.

Industrial agglomeration can affect pollutant discharge in several ways. Firstly, it can reduce the unit cost of pollution by enabling the development of centralized recycling facilities [23]. Previous studies such as Fujita and Tisse [25] and Andersson and Lööf [26] have confirmed that agglomeration can increase firm productivity through increasing economies of scale using firm level data. This is also true in relation to pollution mitigation [21] because processing costs are reduced when firms are agglomerated to take advantage of centralized recycling systems. This is especially true for firms in industrial parks or economic development zones that have been forced to establish sewage treatment systems. China's State Council released the Water Pollution Prevention Action Plan in 2015, whereby development zones were required to establish centralized sewage treatment facilities and install automatic online monitoring devices by 2017. Many industrial parks have responded to the plan by improving their pollutant processing systems [27]. It is particularly efficient to combine waste treatment and pollutant recycling, thereby creating a circular economy in industrial agglomerations [9].

Secondly, agglomeration can reduce the cost of compliance with environmental regulations through centralized management by the government. It has been shown that enforcement of environmental regulations becomes increasingly difficult as the number of firms increases [28]. Similarly, when enterprises are spatially dispersed, regulatory costs will inevitably increase. The government can easily establish regulatory administrative branches in more densely populated 
areas, inhibiting enterprises from illegally discharging pollutants and facilitating punishments for breaches.

Thirdly, agglomeration can promote mutual learning among enterprises in relation to technological upgrading. Urban agglomeration is associated with intense knowledge flows [29-31], and innovative activities are more concentrated and tend to diffuse faster within denser clusters [32-34]. Innovative environmental technologies can be developed and diffused more quickly in dense urban regions, and thus enterprises located in agglomerated regions are more likely to adopt advanced environmentally friendly technologies that are used within the cluster [35]. Flows of technically qualified personnel and clean production technologies tend to be greater in agglomerated regions, stimulating more rapid diffusion of green technology and reducing the levels of pollutants.

Agglomeration can also have a spillover effect on neighboring areas because pollution is transboundary [36], that is, pollution in one location is easily spread to neighboring cities. Airborne pollutants such as sulfur dioxide $\left(\mathrm{SO}_{2}\right)$ and soot are particularly easy to disperse. Therefore, we argue that spatial spillovers through geographically adjacent networks are an important aspect of agglomeration and the resulting pollutant emissions [9]. Agglomeration in one city might affect the intensity of pollutant emissions in neighboring cities in several ways. On one hand, it can promote the intensity of pollutant emissions in other cities due to pollution diffusion. On the other hand, it may reduce neighboring cities' intensity of pollutant emissions through increased pollution process efficiency or the establishment of a pollutant recycling system including neighboring cities in networks. Whether such spillovers exist via social and economic networks needs further empirical tests.

\subsection{Regulations, Social Networks, and Pollutant Emissions Abatement}

Improvements in the environment are mainly based on people's increasing environmental awareness and the government's increasingly stringent regulations in relation to economic development [37]. Strengthened environmental controls may reduce enterprises' sewage treatment costs and reduce the intensity of industrial pollutant emissions [38,39] because enterprises are forced to upgrade their technologies and switch to cleaner production equipment to reduce their emissions [38,40].

The Chinese government is paying more attention to the environment than Western countries did at a comparable stage of their economic development [41-43]. In China, environmental regulations are mostly formulated at the central government level and enforced at the local government level [44]. However, in reality, China's central government has limited capacity to supervise implementation activities at the local level. It is local environmental bureaus that maintain responsibility for environmental quality by supervising polluting enterprises and coordinating planning agencies [6]. The local governments provide annual budgets to local environmental agencies and take charge of personnel allocations. On the other hand, local governments are responsible for developing the economy within their jurisdictions. China's local officials will be promoted when they are able to maintain rapid economic growth in their jurisdictions [6]. Local governments with insufficient budgets are often willing to pursue economic growth at the expense of the environment [45]. More developed cities with less budget pressure, however, have more incentives to formulate and comply with stricter environmental regulations. For example, Beijing has withdrawn 1992 polluting enterprises from 2013 to 2017, and will eliminate more than 1000 general manufacturing and polluting enterprises in the future.

However, environmental regulations can have spillover effects on neighboring cities' pollutant emissions through different channels. It is known that strengthened environmental regulations may lead polluting enterprises to relocate to other regions or states, as noted in the "pollution heaven hypothesis" [6,46-49]. Social and economic networks provide an even closer connection between cities through social or economic connections. Therefore, cities may also be influenced by the regulations of other cities via social networks. Cities can experience both positive and negative environmental effects from other cities. If a city's local government enforces stringent environmental regulations, 
other cities that are connected via social or economic networks tend to follow that city's lead and introduce similar environmental regulation policies, which can lead to a reduction in emissions in those cities [15]. On the other hand, economic activities that are impacted by environmental regulations may be transferred to other cities via social networks. Such transfers might lead to a negative spillover effect of environmental regulations on other cities in the network. Thus, cities with stringent environmental regulations might develop at the expense of other cities' environments. Therefore, a positive correlation between environmental regulations and pollutant emissions in other cities that are connected through social or economic networks is expected, with the net effect dependent on the balance between the two kinds of effects.

\subsection{Technology, Economic Networks, and Pollutant Emissions}

Technological input, regardless of whether it is from the government or from private enterprise, is undoubtedly a significant factor in reducing pollutant emissions [50-53]. New energy technology and information technology can have a positive impact on the environment through improved energy efficiency in production or through a shift in consumption from products to services [53]. China has received a large quantity of international assistances in pollution prevention and clean manufacturing techniques. Among them, Japan has provided the most help in improving China's clean technologies. Japan's New Energy Development Organization has introduced various technologies to China, including better coal cleaning, more efficient combustion and gas desulfurization [43]. China is paying more attention to the growth driven by technology innovation. The 13th Five-Year Plan (2016-2020) promises to support green innovative technology, promote environmentally-friendly products and develop leading environmental technologies in equipment and service models. Local urban governments have taken various measures to develop technology. However, their technical level varies from city to city according to different stages of development and abilities in attracting talents, which would have different impacts on the intensity of pollution emissions.

However, because new knowledge and technology can only be generated in a few districts, the technology adopted by most cities is generated in other regions. Thus, technology spillovers are important [39]. Previous studies such as Cheng et al. [9] have only examined spatial spillover channels in relation to technology. However, technology is more likely to spread through social or economic interactions among people in different regions. Economic benefits are particularly important in driving technology diffusion, and thus we assume that social and economic networks are most important in relation to the spread of clean technology and the subsequent reduction in pollution. Therefore, social networks based on Weibo data and economic networks are integrated into the econometric models to determine whether technology in other cities in a network affects the intensity of local pollutant emissions through different channels, and negative relationships are expected.

\subsection{Spatial Spillovers of Pollutant Emissions}

Environmental pollution intensity may also be affected by pollutant emissions in neighboring regions because in reality, polluted water and air in one area can readily diffuse to surrounding areas [54]. Manufacturing plants that generate pollution can also be spatially correlated with surrounding areas $[55,56]$, and there is often spatial convergence in the adoption of waste treatment facilities and cleaning technologies. Such spatial spillovers of pollutant emissions have been confirmed by Cheng [3] and Cheng et al. [9]. Therefore, it is crucial to control the spatial correlations among regions when considering the influential mechanisms underlying intensity of pollutant emissions.

In summary, the analytical framework can be presented as shown in Figure 1.

China's rapid urbanization, comprehensive implementation of regulations and increasing investment in new technology provide favorable conditions for such a study. Therefore, it is important to investigate how manufacturing industry agglomeration, environmental regulations and technological inputs in various regions affect pollutant emissions. More importantly, by integrating social, economic and spatial networks, this study examines the spillover channels affecting the 
relationships between industrial agglomeration, environmental regulations and technology and intensity of pollutant emissions using prefecture-level data from Chinese cities.

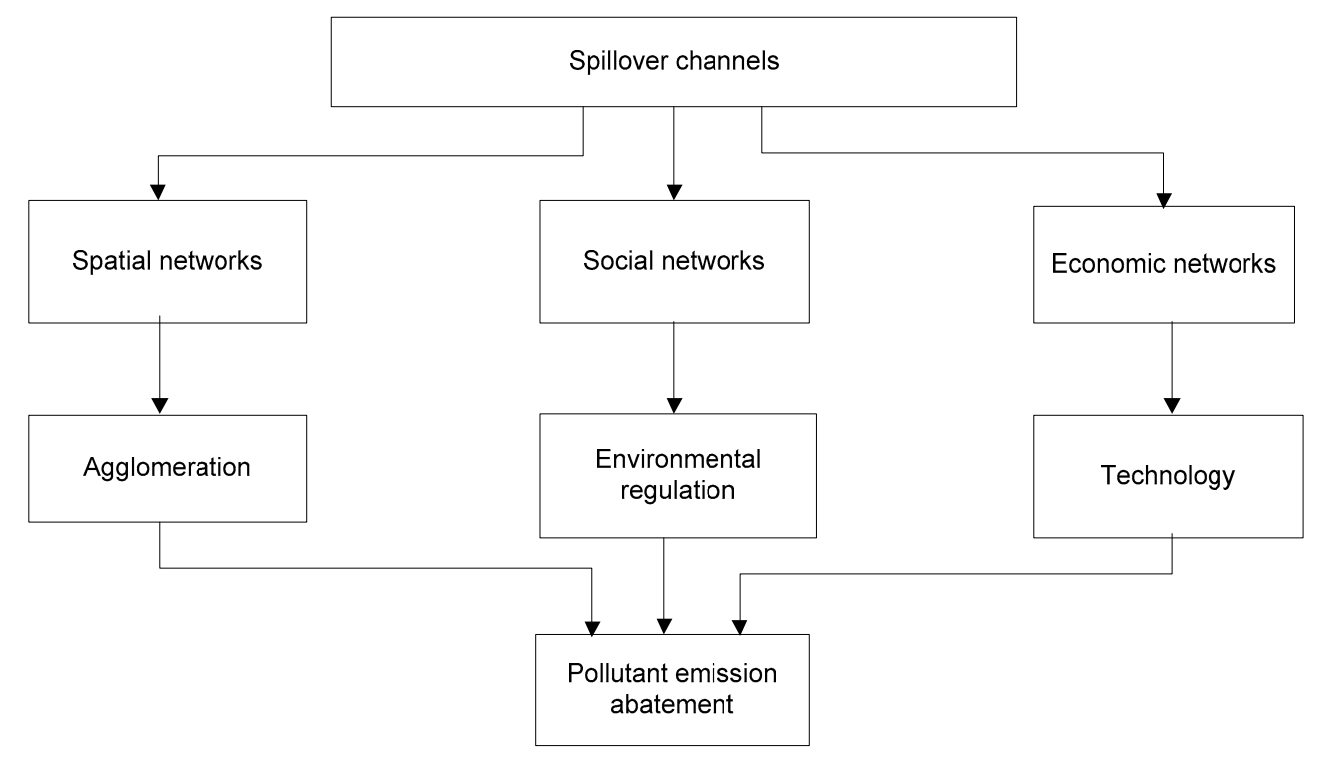

Figure 1. Analytical framework.

\section{Methodology}

\subsection{Definitions and Data Sources}

To consider the spillover effects between cities, three different types of networks, a social network derived from social media, an economic network, and a spatial network, were used to reflect cities' relationships in terms of social media concerns, economic connections, and geographical location, respectively. The social network is the most significant of the three types of network linkages. Social media platforms such as Sina Weibo have become increasingly popular in China in recent years. SINA WEIBO is a Chinese Twitter, and is mostly posted in Chinese. Since the Chinese government has blocked Twitter, people in China have to resort to Weibo to express their opinions and comments [57]. It has over 40 million active users every month and is the most popular public social media in China. Therefore, the big data obtained from Weibo is reliable to illustrate Chinese people's opinions. Environmental pollution issues are always hot topics on Weibo. Since social media data can be used to represent the flow of information, and thus the extent of mutual concern between cities can be used to represent intercity social networks in social science research [15]. Thus, social media data were obtained and integrated with geo-information to construct a social network among cities, and then these networks were used to analyze the intercity social network structure in relation to the environment.

The data is gathered from Sina Weibo for constructing the Weibo social network, and a Web crawler is used to obtain the keywords from Weibo posts. The keywords consisted of the most frequently mentioned environmental topics, including smog, water pollution, air pollution, and pollutant emissions (in Chinese). These keywords reflected people's concerns about the environment. Then, the Weibo ID and time of posting of every environment-related post were collected to provide data on the identity, text, post time, and location of each post. By aggregating the locations of posts at the city level, the total number of environment-related posts were calculated in each city from 2010 to 2016. 
Intercity linkages in relation to environmental issues is constructed using these data. Then, a gravity model is used to construct the Weibo network as follows:

$$
\mathrm{L}_{i j}^{w}=\frac{P_{i} P_{j}}{\mathrm{~d}_{i j}^{2}}
$$

where $\mathrm{L}_{i j}^{w}$ is the total number of Weibo network linkages between city $i$ and city $j, P_{i}$ and $P_{j}$ are the total numbers of Weibo posts that included keywords in city $i$ and $j$, respectively, and $d_{i j}$ is the distance between the two cities.

An economic network is also constructed to represent the economic linkages between the two cities as follows:

$$
\mathrm{L}_{i j}^{e}=\frac{E_{i} E_{j}}{\mathrm{~d}_{i j}^{2}}
$$

where $\mathrm{L}_{i j}^{e}$ is the total number of economic network linkages between city $i$ and city $j, E_{i}$ and $E_{j}$ are the GDP of city $i$ and $j$, respectively, and $\mathrm{d}_{i j}$ is the distance between the two cities.

\subsection{Regression Analysis}

The study aimed to investigate how industrial agglomeration, environmental regulations and technological inputs affect water and air pollutant emissions intensity by introducing social and economic networks to standard econometric models. The data were mainly collected from the China City Statistical Yearbook and patent data collected from the website of National Intellectual Property Administration of China. They are official authoritative data and have been used extensively in Chinese urban studies. Industrial agglomeration, environmental regulations and technology variables are introduced to test the predictions of the paper. Economic openness, urban economic development, industrial structure, and energy intensity variables are also included as control variables, as has been done in previous studies $[19,36,39,58,59]$. The municipality is used as the geographic unit, the time span is 2003-2016, and the calculation is as follows:

$$
\begin{aligned}
\text { lnPollution }_{\text {it }}=\beta_{0} & +\beta_{1} \operatorname{lnVA}_{i t}+\beta_{2} \text { Firms }_{\text {it }}+\beta_{3} \operatorname{lnRegulation~}_{\text {it }} \\
& +\beta_{3} \text { Treatrate }_{i t}+\beta_{5} \text { Techinput }_{i t} \\
& +\beta_{6} \operatorname{lnPatent}_{i t}+\beta_{7} \text { FDI }_{\text {it }} \\
& +\beta_{8} \operatorname{lnGDPPC}_{\mathrm{it}}+\beta_{9} \operatorname{lnIND}_{\mathrm{it}}+\beta_{10} \operatorname{lnTER}_{\mathrm{it}}+\beta_{11} \operatorname{lnEnergy}_{\mathrm{it}}+\alpha_{\mathrm{i}}+\gamma_{\mathrm{t}} \\
& +\varepsilon_{\mathrm{it}}
\end{aligned}
$$

\subsection{Dependent and Independent Variables}

Pollution represents the intensity of pollutant emissions including wastewater pollutant emissions intensity (Wastewater), sulfur dioxide emissions intensity (SulfurDioxide), and soot emissions intensity (Soot). Emissions intensity is defined as the volume of pollutant emissions per industrial value added [8]. Following Ciccone [60], the amount of industrial value added per unit of area in the city $(V A)$ is used to indicate the level of industrial agglomeration. The level of industrial output cannot determine whether the high industrial value added is caused by one big company or a number of small and medium enterprises. Therefore, the number of firms in a city with total sales of more than 5 million Yuan per unit of area (Firms) is introduced as a proxy for external agglomeration.

Regulation denotes the level of urban environmental regulations and is determined by dividing total pollution processing fees by the total amount of pollutant emissions in the city. Since the units used to measure the volume of pollutant emissions differ across the three types of pollutants, regulation intensity is calculated by summing the standardized data relating to pollutant emissions and pollutant processing fees before division. Following Zhou et al. [61], the treatment rate for the volume of sulfur dioxide produced (Treatrate) is incorporated as a proxy for environmental regulations. Environmental policies, such as the Air Pollution Prevention and Control Law designating an acid rain control zone 
and a sulfur dioxide pollution control zone, are often implemented at the national level. New firms that could not use low-sulfur coal were required to install desulfurization facilities or to take other measures to control $\mathrm{SO}_{2}$ emissions, and existing plants were encouraged to control $\mathrm{SO}_{2}$. Emission of $\mathrm{SO}_{2}$ is the main cause of acid rain in China. - However, the enforcement of such policies varied across cities. The percentage of industrial $\mathrm{SO}_{2}$ meeting the standard for emission in a city is thus a good proxy of local governments' attitude towards nation-wide environmental policies and the stringency of environmental regulation at the local level. Both of these introduced variables are expected to have a negative sign in relation to pollutant emissions.

New technology is expected to significantly reduce the volume of emissions, and thus finance expenditure for science and technology of the city (Techinput) is incorporated as a proxy for local technological input, which is expected to have a negative impact on pollutant emissions intensity. Invention patents can be used to represent the cities' level of innovation [62], and thus the cities' numbers of invention patents per capita (Patent) is used as a proxy for the cities' level of technology, which is expected to have a negative sign in relation to emissions intensity.

Other control variables including economic development, economic openness, economic structures, and energy intensity are also incorporated $[6,9,42,56,61]$. Foreign direct investment (FDI) is used to represent the openness of a city and is defined as the FDI that is actually utilized in a given year divided by GDP. GDPPC represents GDP per capita (units of 10,000), which reflects the level of economic development. These figures were adjusted to 2003 constant prices to enable comparisons across periods. IND and TER represent the numbers of secondary and tertiary industries as a proportion of the total GDP of the municipalities, and represent the industrial structure's influence on the environment. Energy intensity might also affect emissions intensity, and thus we include the energy consumption divided by GDP (Energy) of each city in the regression, which is expected to have a positive impact on emissions intensity.

Since city-level data for pollutant processing expenses for the regulation variable are only available until 2007, city-level data for the period 2003-2007 and provincial-level data for the period 2008-2016 are used to measure the regulation variable. In terms of variables, $i$ is the municipal-level city, $t$ is the year, $\alpha_{i}$ is the regional fixed effect, and $\varepsilon_{i t}$ is the error term. dummy variables for industry and year are introduced. The logarithm of continuous variables is used to obtain elasticity results and to reduce the influence of outliers and heteroscedasticity. The variables could be normalized so that the effects of the factors could be compared. However, the panel data seems inappropriate to be normalized as it is done for pooled data model, because it involves many years' data and has to be calculated within and between groups. Introducing one year's normalized pool data into the regression models was also considered, but such data could not reflect the whole picture of pollutant emission variations. Therefore, the absolute value or logarithm form of variables were used in the regression. The definitions and descriptions of the variables are shown in Table 1.

Table 1. Definitions and descriptions of variables used.

\begin{tabular}{|c|c|c|}
\hline & Variable & Definition \\
\hline \multirow{3}{*}{$\begin{array}{l}\text { Dependent } \\
\text { Variables }\end{array}$} & lnWastewater & Wastewater pollutant intensity (logarithm) \\
\hline & lnSulfurDioxide & Sulfur dioxide pollutant intensity (logarithm) \\
\hline & $\ln$ Soot & Soot pollutant intensity (logarithm) \\
\hline Agglomeration & lnFirms & Number of firms (above 5 million Yuan sales value) per unit area of the city (logarithm) \\
\hline \multirow{2}{*}{ Regulation } & Regulation & Environmental regulation level \\
\hline & Treatmentrate & Treatment rate of $\mathrm{SO}_{2}$ production \\
\hline \multirow{5}{*}{$\begin{array}{c}\text { Control } \\
\text { variables }\end{array}$} & FDI & The amount of foreign direct investment as a share of the city's GDP \\
\hline & $\operatorname{lnGDPPC}$ & Per capita GDP of the city at 2003 constant prices (logarithm) \\
\hline & IND & The value of secondary industry outputs as a share of the city's GDP \\
\hline & TER & The value of tertiary industry outputs as a share of the city's GDP \\
\hline & lnEnergy & Energy intensity of the city \\
\hline
\end{tabular}




\subsection{Specification of Weight Matrix}

As previously mentioned, the network spillover effect can be identified by integrating spatial econometrics into the model. Since spatial dependency occurs not only among dependent variable, but also among independent variables, SDM well addresses such a problem [63,64]. Therefore, an SDM is used to analyze the spillover effects of agglomeration, environmental regulations, and technology, and to introduce the spatial lag term for the explanatory variables to the above calculations as follows:

$$
\begin{aligned}
\text { lnPollution }_{\text {it }}=\beta_{0} & +\rho \text { Wlnpollution }_{\text {it }}+\beta_{1} \operatorname{lnVA}_{\text {it }}+\beta_{2} \text { Firms }_{\text {it }}+\beta_{3} \text { lnRegulation }_{\text {it }} \\
& +\beta_{3} \text { Treatrate }_{i t}+\beta_{5} \text { Techinput }_{i t} \\
& +\beta_{6} \operatorname{lnPatent}_{i t}+\mathrm{W} * \lambda * X+\beta_{7} \text { FDI }_{\mathrm{it}} \\
& +\beta_{8} \operatorname{lnGDPPC}_{\mathrm{it}}+\beta_{9} \operatorname{lnIND}_{\mathrm{it}}+\beta_{10} \operatorname{lnTER}_{\mathrm{it}}+\beta_{11} \operatorname{lnEnergy}_{\mathrm{it}}+\alpha_{\mathrm{i}}+\gamma_{\mathrm{t}} \\
& +\varepsilon_{\mathrm{it}}
\end{aligned}
$$

where $W$ is a weight matrix that denotes the network through which the spillover effect occurs and reflects the interactions between connected cities. We employ three weight matrices to identify the types of spillover channels that are occurring. $X$ is a dependent variable denoting the level of agglomeration, environmental regulation and technological input; $\rho$ is the coefficient of the spatial lag of the independent variables; and $\lambda$ represents the coefficient of the spatial lag of the dependent variables.

Based on the above-mentioned Weibo data, economic data, and location information, three kinds of networks are established to reflect the social relationships, economic relationships and geographical relationships, respectively.

(1) Weibo Network Matrix $W_{\text {weibo }}$. This is used to illustrate the impact of social media on spillovers, and the Weibo network is used to represent the degree of social media interaction between cities. The element of matrix $W_{i j}$ is set as a row standardized to $L_{i j}^{w}, W_{i j}=L_{i j}^{w} / \sum_{j} L_{i j}^{w}$, where $L_{i j}^{w}$ indicates the linkage between city $i$ and city $j$ in the Weibo network.

(2) Economic Network Matrix $W_{\text {econ }}$. This is used to illustrate the economic linkages between cities. The element of matrix $W_{i j}$ is set as a row standardized to $L_{i j}^{e}, W_{i j}=L_{i j}^{e} / \sum_{j} L_{i j}^{e}$, where $L_{\mathrm{ij}}^{\mathrm{e}}$ indicates the economic linkage between city $i$ and city $j$.

(3) Geographical Network Matrix $W_{\text {dist }}$. This specifies the square of inversed distance between city $i$ and $j$ within $500 \mathrm{~km}$. This means that the spillover effect only occurs for the sake of geographic location: $W_{i j}=\frac{1}{d_{i j}^{2}} / \sum_{j} \frac{1}{d_{i j}^{2}}$ if $d_{i j}^{2}<500 \mathrm{~km}, 0$ otherwise.

Some studies have used a binary adjacency matrix for $\mathrm{W}$, where the element of the matrix is assigned a value of 1 when two cities are adjacent to each other and 0 otherwise [15]. However, this does not fully reflect the actual spatial relationship because urban areas vary [3]. Thus, the inverse squared distance between two cities within a distance was assigned to the element of the spatial matrix, and then was normalized to the rows of the matrix. Since it is difficult to estimate the scope of the affected area with certainty, a bandwidth of $500 \mathrm{~km}$ is introduced and it is assumed that the spillovers occurred within a radius of $500 \mathrm{~km}$ (We also tried other bandwidths such as $300 \mathrm{~km}$ and $400 \mathrm{~km}$ and obtained similar results).

\section{Results}

\subsection{Distribution of Pollutant Emissions}

The polluted regions are distributed unevenly and are highly agglomerated in just a few regions. Figure 2 shows the distribution of wastewater, sulfur dioxide and soot emissions across Chinese cities in 2016. It can be seen that wastewater emissions are higher in the coastal regions than in the inland regions. The regions around the Yangtze River Delta and the Beijing-Tianjin area are more affected by wastewater pollutants than the inner regions. All of the most polluted regions have a higher population and more industrial activity than other areas. However, the distributions of sulfur dioxide 
and soot pollutant emissions display different patterns. Areas with high levels of sulfur dioxide and soot pollutants are mostly located in northern China, especially in Shanxi and Shaanxi provinces, where there is a lot of coal mining activity and a high incidence of heavy industry that is a source of high levels of pollutant emissions. The Chongqing municipality in southwest China is also a highly polluted region as a result of the high incidence of heavy industry in this area.

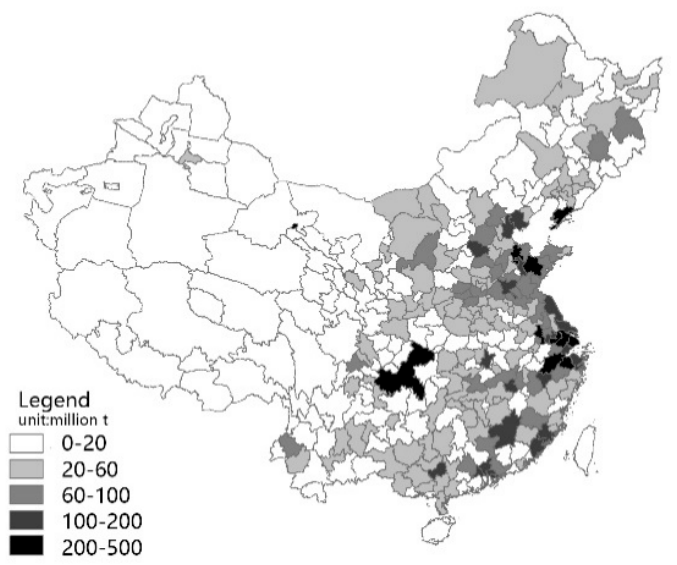

(a)

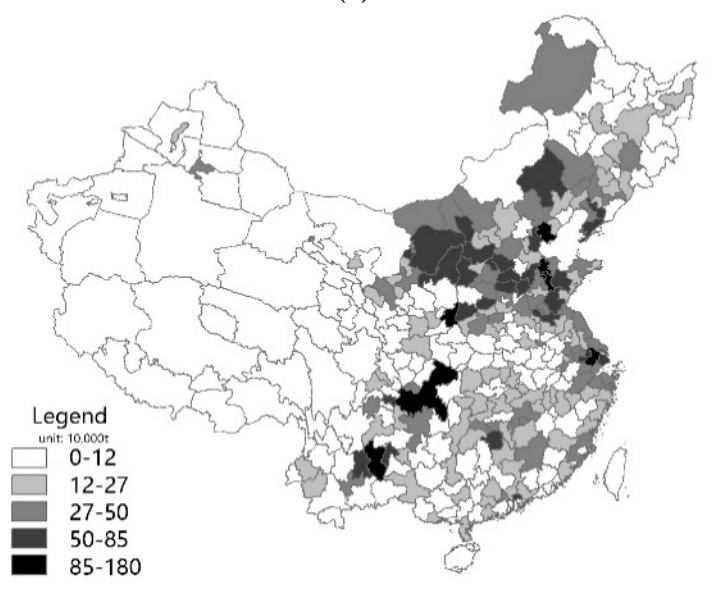

(b)

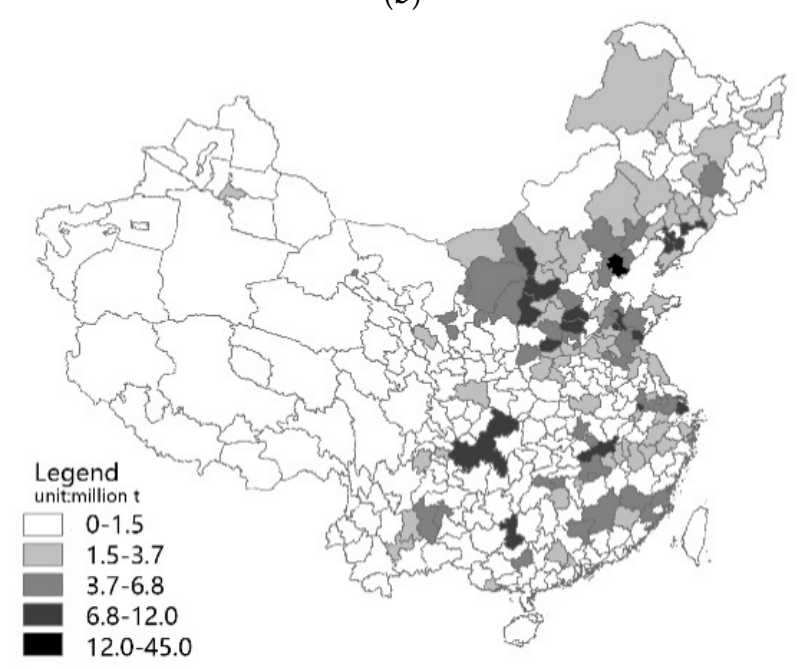

(c)

Figure 2. Spatial distribution of pollutant emissions in China in 2016 (a) waste water, (b) sulfur dioxide, (c) soot. 
The spatial pattern of pollutant emissions intensity, which is calculated by dividing pollutant emissions by the gross value of the industrial outputs of the city, displays a slightly different picture. Figure 3 shows the pollutant emissions intensity distribution for prefectural-level cities across China in 2016. Higher wastewater pollutant emissions intensity cities are mostly distributed in the south and northwest of China, especially in cities in Guangxi province and Shaanxi province. These regions have a greater number of pollutant industries, while the gross value added of these industries is lower than that of industries in the eastern region. The high sulfur dioxide pollutant emissions intensity areas are mostly distributed in the northeast, northwest and southwest of China. The high incidence of heavy industry and the basin-like topography are the main reasons for the high levels of sulfur dioxide pollutant emissions in Guangxi province in the southern part of China.

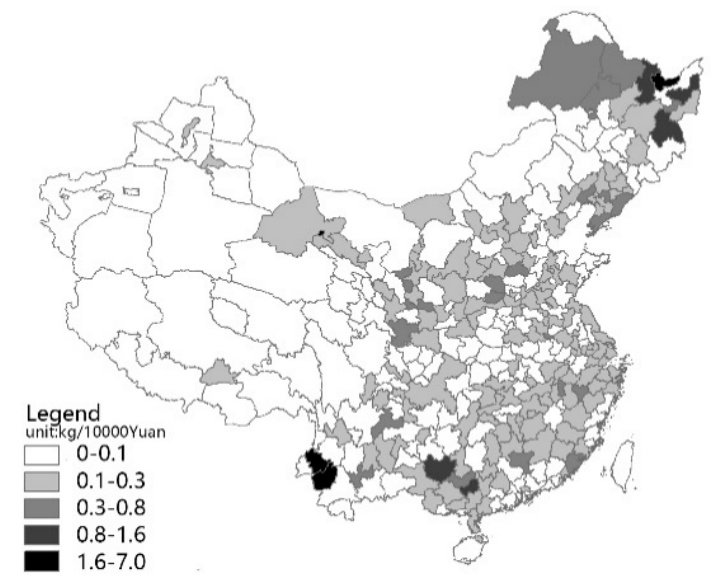

(a)

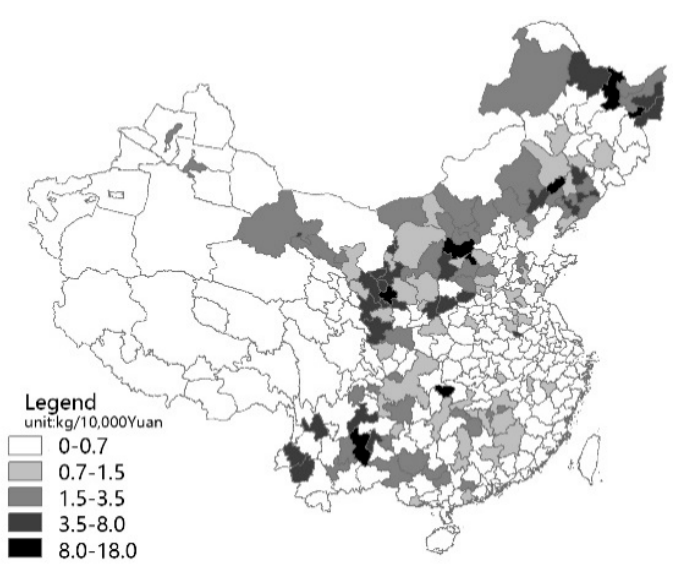

(b)

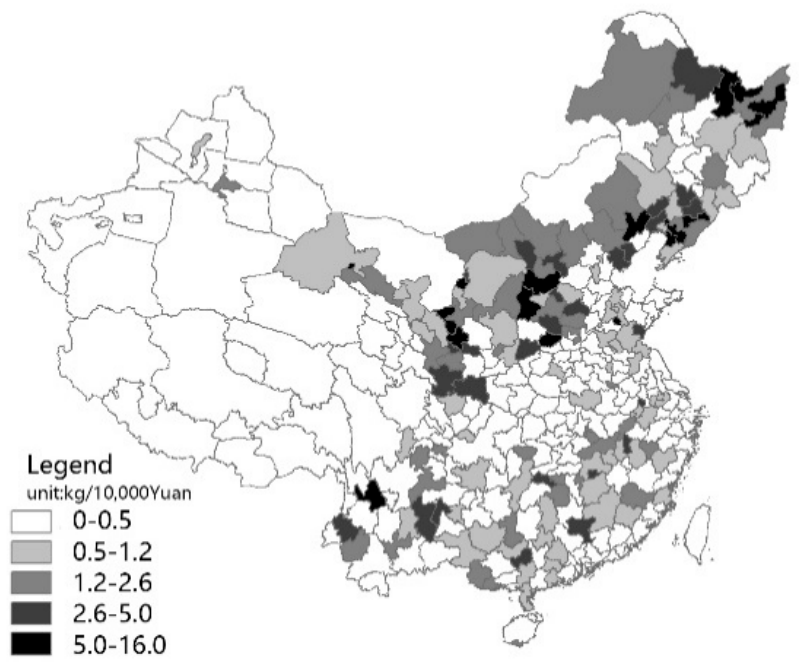

(c)

Figure 3. Spatial distribution of pollutant emissions intensity in China in 2016 (a) waste water, (b) sulfur dioxide, (c) soot.

Since 2000, the distribution of pollutants has tended to move toward the central regions of China, following the trend of industries moving inland [65]. It can be seen from Table 2, that in 2003, the Gini coefficients of the three kinds of pollutant emissions were between 0.5 and 0.55 , while in 2016, the Gini coefficients for wastewater and sulfur dioxide pollutants had fallen to 0.45 and 0.53 , indicating that pollutant emissions are diffusing, along with the industries responsible, into the middle and western parts of China. However, the Gini coefficient for soot pollutant emissions rose a little during the same period, indicating that soot pollutant emissions tended to remain agglomerated. This might be because people have increasingly come to recognize the importance of environmental issues, and because soot 
pollutant emissions are a primary concern, they have been more stringently regulated in the more prosperous areas in China in recent years.

The relationships between cities can be visualized using the networks in the GIS environment. The social and economic linkages among cities as represented by the Weibo network and the economic network, respectively, are shown in Figures 4 and 5. Only the strongest $10 \%$ of linkages are shown for the sake of clarity. These figures reflect the structures of the Weibo network and economic network among cities. The thickness of the lines indicates the strength of the linkage, while the darkness and width of line means the magnitude of links. These networks show different linkage structures to those identified through spatial locations. Regarding the social networks based on Weibo big data, the cities with the strongest linkages are Beijing, Shanghai, Shenzhen, Wuhan, Hangzhou, and Nanjing, while the most linked regions are distributed within or among the Beijing-Tianjin region, the Yangtze River Delta region, and the Pearl River Delta region. People in these regions display the greatest concern regarding environmental issues via social media. As for the economic networks, the cities with the strongest linkages are Beijing, Shanghai, Chengdu, Shenzhen, and Guangzhou. The most linked regions are located in the eastern part of China, while some of the regional centers in the western and middle parts of China, such as Chengdu, Chongqing, Xian, Zhengzhou, Wuhan, and Changsha, also have strong linkages with other cities.

Table 2. Gini coefficients of pollutant emissions distributions in 2003 and 2016.

\begin{tabular}{cccc}
\hline Gini & Waste Water & Sulfur Dioxide & Soot \\
\hline 2003 & 0.55 & 0.50 & 0.50 \\
2016 & 0.51 & 0.45 & 0.53
\end{tabular}

Source: Author calculations using data collected from the China City Statistical Yearbook.

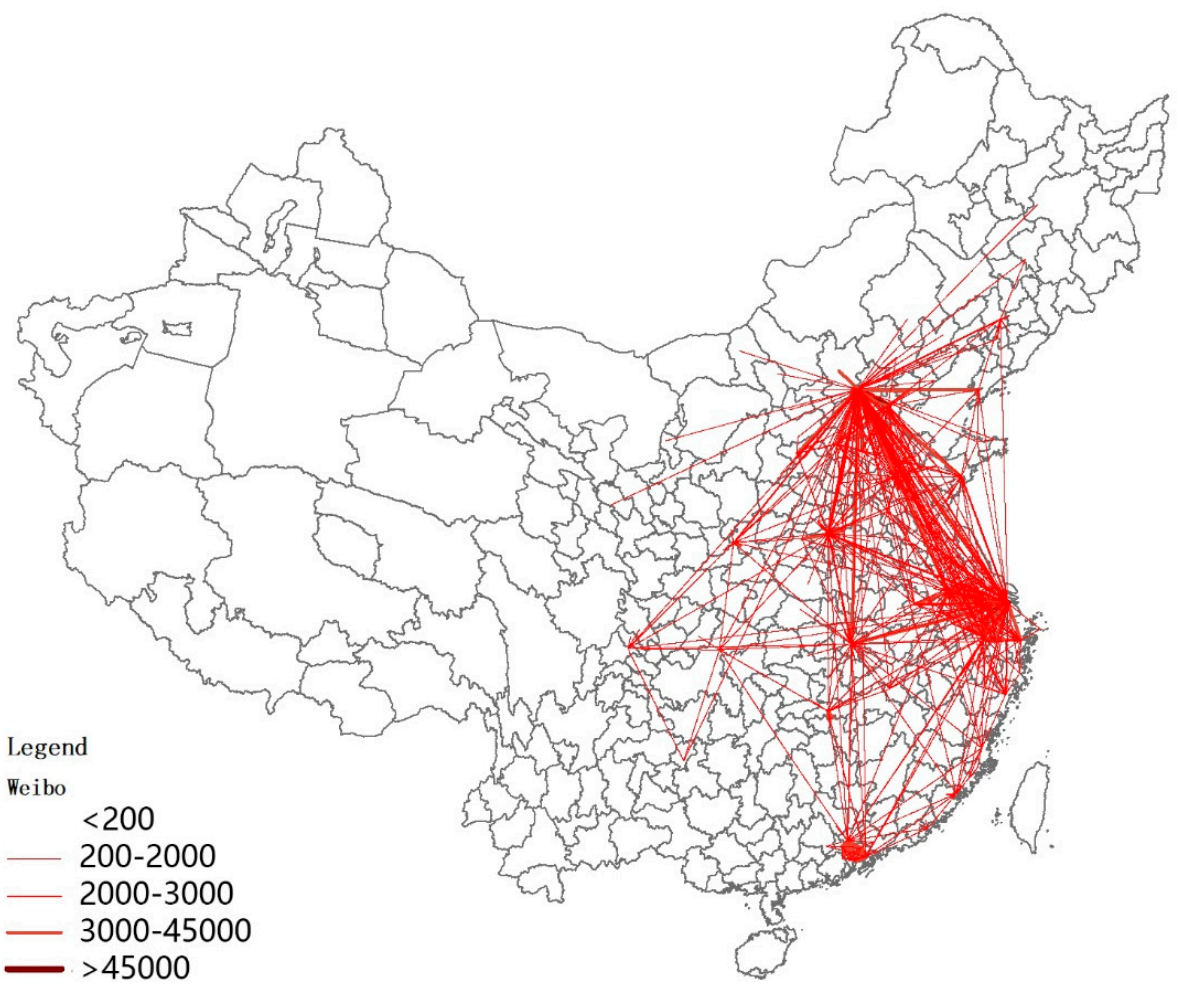

Figure 4. Main Weibo networks among prefecture cities in China. 


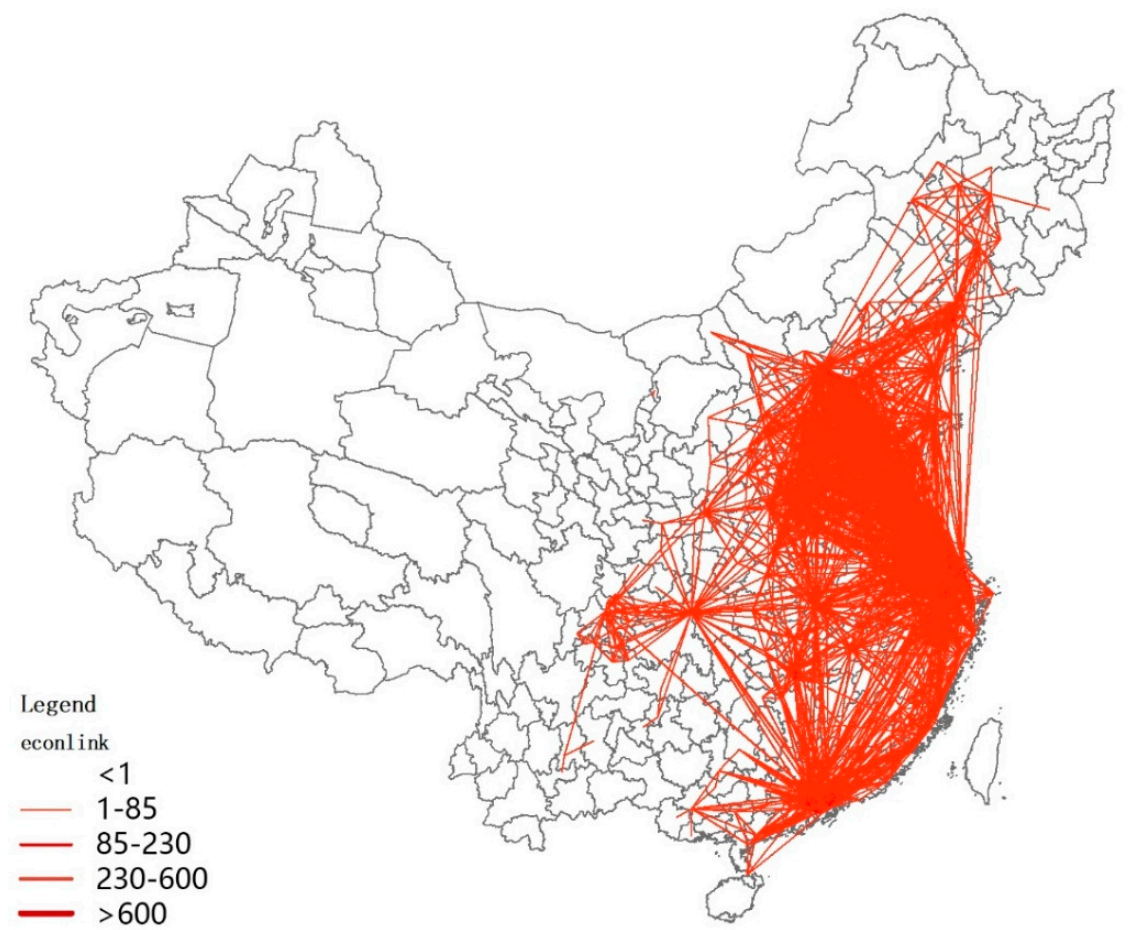

Figure 5. Main economic networks among prefecture cities in China.

\subsection{Findings from Integrated Regression Models}

The coefficients of $\ln G D P P C, \ln V A, I N D$, and TER are all greater than 0.5 (see Appendix A Table A1), so we dropped $\ln P G D P$ and TER to eliminate multicollinearity problems. The descriptions of the variables are presented in Appendix A Table A2. The results of the estimations are shown in Tables 3-5. Table 3 shows the results of introducing the social network to test the spillover effects of agglomeration, environmental regulations and technological inputs on environmental pollution. Table 4 shows the results of introducing the economic network to test the spillover effect of economic speculation. Table 5 shows the results of introducing the spatial matrix based on geographic locations to explore the spatial spillovers. In each table, columns 1, 2 and 3 show wastewater emissions intensity, sulfur dioxide emissions intensity, and soot emissions intensity, respectively, as the dependent variable.

Table 3. Regression results with social network matrix integrated.

\begin{tabular}{cccc}
\hline Variables & Waste Water & SO $_{2}$ & Soot \\
\hline lnVA & $-0.174^{* *}$ & $-0.187^{* *}$ & $-0.286^{* *}$ \\
lnFirms & $0.095^{* * *}$ & $0.022^{* *}$ & -0.307 \\
Regulation & $-0.250^{* * *}$ & $-0.373^{* *}$ & $-0.376^{* * *}$ \\
Treatrate & $-0.158^{* * *}$ & $-0.607^{* * *}$ & $-0.306^{* * *}$ \\
Techinput & $-0.083^{* * *}$ & $-0.133^{* * *}$ & $-0.099^{* *}$ \\
lnPatent & $0.007^{* *}$ & $-0.019^{* *}$ & 0.032 \\
$\mathrm{~W}_{\text {weibo }}{ }^{*} \ln$ HA & $-0.311^{* *}$ & $-0.309^{* *}$ & -0.169 \\
$\mathrm{~W}_{\text {weibo }}{ }^{*}$ InFirms & $0.878^{* * *}$ & $-0.474^{* *}$ & $-0.653^{* *}$ \\
$\mathrm{~W}_{\text {weibo }}{ }^{*}$ Regulation & $0.175^{* * *}$ & $0.252^{* * *}$ & $0.248^{* * *}$ \\
$\mathrm{~W}_{\text {weibo }}{ }^{*}$ Treatrate & $0.032^{* *}$ & $0.444^{* * *}$ & $0.333^{* * *}$ \\
$\mathrm{~W}_{\text {weibo }}{ }^{*}$ Techinput & 0.010 & $0.083^{* *}$ & 0.047 \\
$\mathrm{~W}_{\text {weibo }}{ }^{*}$ InPatent & $-0.057^{*}$ & $0.026^{* * *}$ & 0.035 \\
FDI & 0.126 & $0.228^{* * *}$ & $-0.215^{* * *}$ \\
IND & $-0.015^{* * *}$ & -0.006 & $-0.012^{* *}$ \\
\hline
\end{tabular}


Table 3. Cont.

\begin{tabular}{cccc}
\hline Variables & Waste Water & $\mathbf{S O}_{2}$ & Soot \\
\hline lnEnergy & $0.476^{* * *}$ & $0.300^{* * *}$ & 0.242 \\
$\rho$ & $0.387^{* * *}$ & $0.427^{* * *}$ & $0.451^{* * *}$ \\
Constant & $8.936^{* * *}$ & $8.402^{* * *}$ & $7.871^{* * *}$ \\
Observations & 3682 & 3682 & 3682 \\
$\mathrm{R}^{2}$ & 0.547 & 0.567 & 0.568 \\
$\mathrm{R}^{2}$ _within & 0.710 & 0.706 & 0.582 \\
\hline
\end{tabular}

${ }^{* * *} p<0.01,{ }^{* *} p<0.05,{ }^{*} p<0.1$

Table 4. Regression results with economic network matrix integrated.

\begin{tabular}{|c|c|c|c|}
\hline Variables & Waste Water & $\mathrm{SO}_{2}$ & Soot \\
\hline $\operatorname{lnVA}$ & $-0.151^{* *}$ & $-0.182 *$ & $-0.278^{* *}$ \\
\hline lnFirms & -0.042 & -0.023 & -0.312 \\
\hline Regulation & $-0.254^{* * *}$ & $-0.355^{* *}$ & $-0.357^{* * *}$ \\
\hline Treatrate & $-0.105 *$ & $-0.602 * * *$ & $-0.301^{* * *}$ \\
\hline Techinput & $-0.101^{* * *}$ & $-0.128 * * *$ & $-0.089 * *$ \\
\hline lnPatent & 0.008 & -0.020 & 0.023 \\
\hline $\mathrm{W}_{\text {econ }}{ }^{*} \ln \mathrm{VA}$ & $-0.290^{* *}$ & -0.178 & -0.098 \\
\hline $\mathrm{W}_{\text {econ }}{ }^{*} \ln$ Firms & $1.619^{* * *}$ & -0.063 & -0.368 \\
\hline $\mathrm{W}_{\text {econ }}{ }^{*}$ Regulation & 0.076 & 0.175 & 0.013 \\
\hline $\mathrm{W}_{\text {econ }}{ }^{*}$ Treatrate & $-0.433^{* * *}$ & 0.195 & 0.089 \\
\hline $\mathrm{W}_{\text {econ }}{ }^{*}$ Techinput & 0.074 & 0.094 & 0.055 \\
\hline $\mathrm{W}_{\text {econ }}{ }^{*} \ln$ Patent & $-0.117^{* *}$ & $-0.053 * *$ & -0.094 * \\
\hline FDI & 0.049 & $0.183^{* * *}$ & $-0.199 * *$ \\
\hline IND & $-0.017^{* * *}$ & -0.005 & $-0.011 *$ \\
\hline lnEnergy & $0.493^{* * *}$ & $0.270 *$ & 0.198 \\
\hline$\rho$ & $0.422 * * *$ & $0.529 * * *$ & $0.529^{* * *}$ \\
\hline Constant & $7.849 * * *$ & $6.382 * * *$ & $6.406^{* * *}$ \\
\hline Observations & 3682 & 3682 & 3682 \\
\hline $\mathrm{R}^{2}$ & 0.557 & 0.563 & 0.572 \\
\hline $\mathrm{R}^{2}$ _within & 0.713 & 0.702 & 0.577 \\
\hline
\end{tabular}

Table 5. Regression results with spatial network matrix integrated.

\begin{tabular}{|c|c|c|c|}
\hline Variables & Waste Water & $\mathrm{SO}_{2}$ & Soot \\
\hline $\operatorname{lnVA}$ & $-0.124 *$ & $-0.171^{*}$ & $-0.293^{* *}$ \\
\hline lnFirms & -0.224 & -0.073 & -0.351 \\
\hline Regulation & $-0.256^{* * *}$ & $-0.384^{* *}$ & $-0.382 * * *$ \\
\hline Treatrate & -0.054 & $-0.534 * * *$ & $-0.252 * *$ \\
\hline Techinput & $-0.100 * * *$ & $-0.127^{* * *}$ & $-0.082 *$ \\
\hline lnPatent & 0.008 & -0.019 & 0.023 \\
\hline $\mathrm{W}_{\text {dist }}{ }^{*} \ln \mathrm{VA}$ & -0.063 & 0.062 & 0.146 \\
\hline $\mathrm{W}_{\text {dist }}^{*} \ln$ Firms & $3.113^{* * *}$ & $-2.674^{* *}$ & $-4.628^{* * *}$ \\
\hline $\mathrm{W}_{\text {dist }}{ }^{*}$ Regulation & $-0.718^{* * *}$ & -0.099 & -0.512 \\
\hline$W_{\text {dist }}{ }^{*}$ Treatrate & $-0.684^{* * *}$ & 0.194 & -0.173 \\
\hline $\mathrm{W}_{\text {dist }}{ }^{*}$ Techinput & 0.146 & 0.139 & 0.091 \\
\hline $\mathrm{W}_{\text {dist }}{ }^{*} \ln$ Patent & $-0.618^{* *}$ & -0.431 & 0.542 \\
\hline FDI & $-0.170 * *$ & 0.003 & $-0.147^{*}$ \\
\hline IND & $-0.025^{* * *}$ & $-0.013^{* *}$ & $-0.015^{* *}$ \\
\hline lnEnergy & $0.582 * * *$ & $0.281 * *$ & 0.251 \\
\hline$\rho$ & $0.767^{* * *}$ & $0.854^{* * *}$ & $0.836^{* * *}$ \\
\hline Constant & $3.662 * * *$ & $2.798^{* * *}$ & $3.246^{* * *}$ \\
\hline Observations & 3682 & 3682 & 3682 \\
\hline $\mathrm{R}^{2}$ & 0.555 & 0.539 & 0.548 \\
\hline $\mathrm{R}^{2}$ _within & 0.701 & 0.660 & 0.534 \\
\hline
\end{tabular}


The results largely confirm our expectations, that is, industrial agglomeration can lead to a significant reduction in pollutant emissions. The results presented in Table 3 show that the intensity of wastewater, sulfur dioxide and soot pollutant emissions decrease by $1.7 \%, 1.9 \%$, and $2.9 \%$, respectively, when industrial agglomeration increases by $10 \%$. The coefficient for environmental regulations is significantly negative for all three kinds of pollutant emissions, indicating that environmental regulations can reduce the intensity of pollutant emissions, which is consistent with the findings of previous studies $[5,61,66,67]$. The estimate effects are persistent across the specifications in Tables $3-5$. Financial support for $R \& D$ has a significant positive effect on pollutant emissions intensity in all three cases, while the number of patents per capita has no impact on pollutant emissions. Similar results are obtained when we introduce the social and economic networks, as shown in Tables 4 and 5 respectively. Technological input from the government can be used to improve emissions processing equipment, thereby quickly reducing emissions. However, patents cannot be used immediately by the local agent, and thus are more likely to be used by people in related cities.

The other coefficients show the expected signs. Foreign investment does not have a significant effect on wastewater emissions, but can significantly improve sulfur dioxide emissions, and reduced the soot emissions, as shown in Tables 3 and 4. The share of secondary industry has a significant negative effect on water and soot pollutant emissions intensity in all cases, possibly because of the more efficient treatment of pollutant emissions in regions with a higher incidence of industry. Energy intensity has a positive effect on wastewater and sulfur dioxide pollutant emissions intensity, which is loosely consistent with a previous finding that higher energy intensity contributes to more pollutant emissions [68].

Tables 3-5 show the regression results for the SDM under $W_{\text {weibo }}, W_{\text {econ }}$ and $W_{\text {dist }}$, respectively. The SDM recognizes the network spillover effects of agglomeration, environmental regulations and technology through the coefficients of interactions between the three matrices and the dependent variables.

Tables 3-5 shows the results of spillovers through social, economic, and spatial networks, respectively. The $\rho$ values denote the spillovers of pollutant emissions in other cities in the networks on the pollutant emissions intensity of the target city. All of the $\rho$ values in the three tables are significantly positive, indicating positive spillovers through all three kinds of networks, although the results for the spatial network, shown in Table 5, are significantly higher than those for the other two channels. This is not surprising, given that pollutant emissions are mainly spread across geographical areas $[3,69]$. It can also be seen from Tables 4 and 5 that the $\rho$ values for sulfur dioxide and soot are higher than that for wastewater, confirming that air pollution always spreads further than wastewater pollution.

The three kinds of network channels influence spillovers in different ways. Regarding the spillover effect of industrial agglomeration on pollutant emissions intensity, we found that the coefficients of $W_{\text {weibo }}{ }^{*} \ln V A$ are significantly negative in relation to wastewater and sulfur dioxide emissions, and those of $W_{\text {weibo }}{ }^{*} \ln$ Firms shown in Table 3 are significantly negative in relation to $\mathrm{SO}_{2}$ and soot emissions. This effect is barely evident in Table 4, which shows the results of introducing the economic network, while the coefficients of $W_{\text {dist }}{ }^{*} \ln$ Firms in Table 5 show a significant reduction in sulfur dioxide and soot emissions intensity. This suggests that social network-related industrial agglomeration of cities tends to reduce the local city's pollutant emissions, but such spillovers can hardly be prompted by economic networks. Geographic location also plays a vital role in the effect of spillovers from industrial agglomeration on pollutant emissions.

Regarding environmental regulations spillover to other cities, it can be seen that the coefficients of $W_{\text {weibo }}{ }^{*}$ Regulation and $W_{\text {weibo }}{ }^{*}$ Treatrate shown in Table 3, which integrate the social network, have a significant positive effect on pollutant emissions, while they are insignificant in the other two spillover channels. This indicates that other social related cities' environmental regulation in the social network might worsen the environment of the local environment. It is known that environmental regulations are mostly transferred through social networks, especially among cities with similar ideas regarding environmental protection. However, the results show that such spillovers are increasing pollutant 
emissions in social media-linked cities. This indicates that more pollutant industries might transfer to social media-linked cities, consistent with the "not-in-my-backyard" phenomenon, whereby local governments toughen their environmental regulations to keep polluting firms from locating within their jurisdictions [70]. Toughening their regulations will improve their own environment, but at the price of increased environmental pollution in social media-related cities. It appears that the interactions of spatial matrices and environmental regulations are significantly negative in relation to wastewater emissions, as shown in Table 5, indicating that neighboring cities' regulations might help to reduce a city's wastewater emissions, but have no effect on $\mathrm{SO}_{2}$ and soot emissions.

The technology spillover effect on pollutant emissions through networks is significantly negative under $W_{\text {econ }}{ }^{*} \ln$ Patent, although the technology input's ( $W^{*}$ Techinput) spillovers have no effect. These spillovers are not significant under $W_{\text {weibo }}$ and $W_{\text {dist }}$, indicating that neither the existence of a social network nor spatial proximity leads to the diffusion of clean technology. An economic network is the only means by which clean technology can be diffused to other cities, thereby lowering the pollutant emissions intensity in those cities.

In summary, the results show that the spillover channels differ for different variables. For spillover effects of industrial agglomeration on pollutant emissions, social network and spatial proximity are the most important channels. Industrial agglomeration not only reduces a city's pollutant emissions, but also reduces emissions in cities that are related through social and spatial networks. Environmental regulations have a negative spillover effect on related cities' environments through social networks. Stringent regulations in one city can cause social media-linked cities to face increased environmental pressure, but more pollutant emissions social media-linked cities are mainly caused by pollution transfer. However, new technology can significantly reduce the pollutant emissions intensity of cities in an economic network.

\section{Discussion}

Pollutant emissions abatement has attracted increasing attention from both governments and researchers. Previous studies have stressed the importance of the effects of industrial agglomeration, economic development, R\&D, environmental regulations, and local economic structures on pollutant emissions. However, less attention has been paid to the way in which different spillover channels affect pollutant emissions reduction. Thus, this study aimed to identify the effects of industrial agglomeration, environmental regulations and technology on pollutant emissions, as well as the spillover channels related to these factors by integrating social and economic networks.

In this study, spatial econometric analysis and network analysis were used to investigate the influential factors and their spillovers on the intensity of urban pollutant emissions. The results show that industrial agglomeration, environmental regulations and technological inputs facilitate emissions intensity abatement. The results also confirm that these factors affect the intensity of pollutant emissions in neighboring regions through social, economic and spatial networks. These findings highlight the network linkages and spillover channels affecting the intensity of pollutant emissions.

More specifically, it appears that spatial distributions and intensity distributions are different in relation to different types of pollutant emissions. Coastal regions showed the highest levels of wastewater pollutants, while the highest levels of sulfur dioxide and soot pollutant emissions were located in provinces such as Shanxi, Shaanxi, Inner Mongolia, and Chongqing municipality that have a high incidence of coal production. However, the distribution of pollutant emissions intensity showed a different pattern. High wastewater pollutant emissions intensity was mainly located in Guangxi province, high sulfur dioxide pollutant emissions intensity was located in the northwest and southwest regions, and high soot pollutant emissions intensity was located in regions with abundant coal resources such as Shanxi, Shaanxi and Heilongjiang provinces.

Using prefecture-level panel data from 2003 to 2016, how industrial agglomeration, environmental regulations, and technological inputs affect pollution abatement and spillover channels were investigated using SDMs. The results showed that industrial agglomeration, environmental regulations 
and technological inputs facilitate abatement of pollutant emissions intensity. These outcomes can be attributed to the scale effect of pollution processing, the sharing of pollution treatment facilities and the government's centralized management of more agglomerated regions.

By introducing social, economic, and spatial networks, it can be found that there are significant spillover effects of agglomeration, environmental regulations and technology on pollutant emissions intensity through different channels. Spatial spillovers exist in pollutant emissions and agglomerations on pollutant emissions. The pollutant emissions have significant positive spillover effects on the neighboring regions, and the industrial agglomerations in one city could also raise the pollutant intensity of the surrounding areas. We also found social and economic spillover channels through which regulations and technology can have a significant impact on pollutant emissions in related cities within networks. The environmental regulations in one city in a social network might improve the other cities' performance in terms of emissions. However, new technology might reduce emissions in other cities in an economic network. The results also confirm that FDI, industrial structure and energy intensity can have a significant impact on pollution emissions intensity.

The results have several implications. Cities should strive to strengthen industrial agglomeration and promote environmental regulations and technology to reduce the intensity of pollutant emissions. Local governments should strengthen industrial clusters or industrial parks to reduce pollution control cost. More importantly, this study provides evidence that the intensity of pollutant emissions is affected by spillover effects of other relevant cities in social, economic and spatial networks. Network spillovers should be taken into consideration when considering pollutant abatement measures because pollutant emissions and the influential factors are conveyed not only through spatial networks but also through social and economic networks. The results show that a city might develop pollution abatement measures at the cost of neighboring regions because of environmental regulations spillovers through social networks. Since technology in one city can spillover to other cities through economic networks, strengthening economic linkages with technology centers is an effective way to reduce pollutant emissions. Therefore, pollutant emissions abatement should be seen as a systemic process and should not be undertaken by a single local authority without considering other cities that are connected through various types of networks. Higher levels of government should coordinate the governance of the environment in networked cities.

This study provides a new perspective on sustainability research by integrating social and economic networks into existing econometric models using social media data. However, the mechanisms by which different channels affect pollutant emissions abatement require further exploration. Further, we have not yet fully considered how the scale of operation affects the factors influencing pollution reduction. Different spatial scales, that is, whether the pollution is at the city, regional, or national level, will affect the results, and the policy implications will differ for various levels of government. Moreover, the social and economic networks might differ at various scales. Therefore, whether the results found in this study are applicable to different scales needs further exploration.

Author Contributions: J.W. designed and wrote the paper. X.Y. contributed to the network methodologies and modified the draft. Y.D.W. contributed to the conceptual framework and modeling and improved the writing.

Funding: This work was supported by Fundamental Research Funds for the Central Universities (2017ECNU-YYJ036), the National Natural Science Foundation of China (41430637), the US National Science Foundation (1759746) and Key Project of Chinese Ministry of Education, No. 13JJD790008.

Conflicts of Interest: The authors declare no conflict of interest. 


\section{Appendix A}

Table A1. Pearson correlations among dependent variables.

\begin{tabular}{|c|c|c|c|c|c|c|c|c|c|c|c|}
\hline & $\operatorname{lnVA}$ & lnFirms & Regulation & Treatrate & Techinput & lnPatent & FDI & $\operatorname{lnGDPPC}$ & IND & TER & lnEnergy \\
\hline $\operatorname{lnVA}$ & 1.00 & & & & & & & & & & \\
\hline lnFirms & 0.63 & 1.00 & & & & & & & & & \\
\hline Regulation & -0.11 & 0.06 & 1.00 & & & & & & & & \\
\hline Treatrate & 0.40 & 0.08 & -0.14 & 1.00 & & & & & & & \\
\hline Techinput & 0.60 & 0.38 & -0.21 & 0.46 & 1.00 & & & & & & \\
\hline lnPatent & 0.47 & 0.58 & 0.04 & 0.12 & 0.41 & 1.00 & & & & & \\
\hline FDI & -0.07 & 0.00 & -0.07 & -0.10 & 0.00 & -0.02 & 1.00 & & & & \\
\hline $\ln G D P P C$ & 0.65 & 0.45 & -0.10 & 0.36 & 0.64 & 0.48 & 0.11 & 1.00 & & & \\
\hline IND & 0.45 & 0.16 & -0.06 & 0.10 & 0.10 & 0.04 & -0.03 & 0.46 & 1.00 & & \\
\hline TER & 0.10 & 0.23 & 0.06 & 0.13 & 0.30 & 0.38 & -0.03 & 0.23 & -0.62 & 1.00 & \\
\hline lnEnergy & -0.02 & 0.04 & 0.07 & -0.13 & -0.28 & 0.06 & 0.00 & -0.03 & 0.17 & -0.01 & 1.00 \\
\hline
\end{tabular}

Table A2. Descriptions of variables.

\begin{tabular}{ccccc}
\hline Variable & Mean & Stdard Deviation & Min & Max \\
\hline lnWastewater & 7.050 & 0.936 & 3.985 & 10.049 \\
lnSulfurDioxide & 6.922 & 1.123 & 1.498 & 10.506 \\
lnSoot & 6.084 & 1.398 & 1.188 & 9.863 \\
lnVA & 6.024 & 1.563 & 1.277 & 11.168 \\
lnFirms & 0.134 & 0.208 & 0.001 & 1.698 \\
Regulation & 0.148 & 0.256 & 0.000 & 3.828 \\
Treatrate & 0.263 & 0.221 & 0.001 & 0.996 \\
Techinput & 7.402 & 1.389 & 3.892 & 13.872 \\
lnPatent & 0.276 & 0.484 & 0.001 & 4.658 \\
FDI & 0.033 & 0.044 & 0.000 & 0.541 \\
IND & 48.063 & 10.743 & 15.685 & 85.921 \\
lnEnergy & 0.129 & 0.112 & 0.006 & 1.266 \\
\hline
\end{tabular}

\section{References}

1. Gu, B.; Ju, X.; Wu, Y.; Erisman, J.; Bleeker, A.; Reis, S.; Sutton, M.; Lam, S.; Chen, D.; Oenema, O.; et al. cleaning up nitrogen pollution may reduce future carbon sinks. Glob. Environ. Chang. 2018, 48, 56-66. [CrossRef]

2. Zhao, C.; Wu, Y.; Ye, X.; Wu, B.; Kudva, S. The direct and indirect drag effects of land and energy on urban economic growth in the yangtze river delta, china. Environ. Dev. Sustain. 2018. [CrossRef]

3. Cheng, Z. The spatial correlation and interaction between manufacturing agglomeration and environmental pollution. Ecol. Indic. 2016, 61, 1024-1032. [CrossRef]

4. Kyriakopoulou, E.; Xepapadeas, A. Environmental policy, first nature advantage and the emergence of economic clusters. Reg. Sci. Urban Econ. 2013, 43, 101-116. [CrossRef]

5. Shen, J.; Wei, Y.D.; Yang, Z. The impact of environmental regulations on the location of pollution-intensive industries in China. J. Clean. Prod. 2017, 148, 785-794. [CrossRef]

6. Zheng, D.; Shi, M. Multiple environmental policies and pollution haven hypothesis: Evidence from China's polluting industries. J. Clean. Prod. 2017, 141, 295-304. [CrossRef]

7. Lange, A.; Quaas, M.F. Economic Geography and the Effect of Environmental Pollution on Agglomeration. J. Econ. Anal. Policy 2007, 7, 1-31. [CrossRef]

8. Lu, M.; Feng, H. Agglomeration and emission reduction: How urban scale affect industrial pollution intensity? World Econ. (Chin. Ed.) 2014, 7, 86-114.

9. Cheng, Z.; Li, L.; Liu, J. Identifying the spatial effects and driving factors of urban PM 2.5 pollution in China. Ecol. Indic. 2017, 82, 61-75. [CrossRef]

10. Ye, X.; Liu, X. Introduction: Cities as social and spatial networks. In Cities as Social and Spatial Networks; Springer: Cham, Switzerland, 2018; pp. 227-238.

11. Yang, C.; Xiao, M.; Ding, X.; Tian, W.; Zhai, Y.; Chen, J.; Liu, L.; Ye, X. Exploring human mobility patterns using Geo-Tagged social media data at the group level. J. Spat. Sci. 2018. [CrossRef] 
12. Zhen, F.; Qin, X.; Ye, X.; Sun, H.; Luosang, Z. Analyzing Urban Development Patterns Based on the Flow Analysis Method. Cities 2018. [CrossRef]

13. Peng, S.; Yu, S.; Mueller, P. Social networking big data: Opportunities, solutions, and challenges. Future Gen. Comput. Syst. 2018, 86, 1456-1458. [CrossRef]

14. Ter Wal, A.L.J.; Boschma, R.A. Applying social network analysis in economic geography: Framing some key analytic issues. Ann. Reg. Sci. 2009, 43, 739-756. [CrossRef]

15. Chong, Z.; Qin, C.; Ye, X. Environmental regulation and industrial structure change in china: Integrating spatial and social network analysis. Sustainability 2017, 9, 1465. [CrossRef]

16. Kay, S.; Zhao, B.; Sui, D. Can social media clear the air? A case study of the air pollution problem in chinese cities. Prof. Geogr. 2015, 67, 313-351. [CrossRef]

17. Li, Q.; Wei, W.; Xiong, N.; Feng, D.; Ye, X.; Jiang, Y. Social media research, human behavior, and sustainable society. Sustainability 2017, 9, 384. [CrossRef]

18. Verhoef, E.T.; Nijkamp, P. Externalities in urban sustainability: Environmental versus localization-type agglomeration externalities in a general spatial equilibrium model of a single-sector monocentric industrial city. Ecol. Econ. 2002, 40, 157-179. [CrossRef]

19. Lee, S.; Ohb, D. Economic growth and the environment in China: Empirical evidence using prefecture level data. China Econ. Rev. 2015, 36, 73-85. [CrossRef]

20. Arrow, K.; Bolin, B.C.R.; Folke, C.; Holling, C.S.; Janson, B.; Levin, S.; Maler, K.; Perrings, C.; Pimental, D.; Cole, M.A. Economic growth, carrying capacity, and the environment; Trade, the pollution haven hypothesis and environmental kuznets curve: Examining the linkages. Sci. Ecol. Econ. 1995, 15, 91-95. [CrossRef]

21. Zeng, D.Z.; Zhao, L. Pollution havens and industrial agglomeration. J. Environ. Econ. Manag. 2009, 58, 141-153. [CrossRef]

22. Berliant, M.; Peng, S.; Wang, P. Taxing pollution: Agglomeration and welfare consequences. Econ. Theory 2014, 55, 665-704. [CrossRef]

23. He, C.; Huang, Z.; Ye, X. Spatial heterogeneity of economic development and industrial pollution in urban China. Stoch. Environ. Res. Risk Assess. 2014, 28, 767-781. [CrossRef]

24. Krugman, P.R. Increasing returns and economic geography. J. Polit. Econ. 1991, 99, 483-499. [CrossRef]

25. Fujita, M.; Thisse, J.F. Economics of Agglomeration: Cities, Industrial Location and Regional Growth; Cambridge University Press: Cambridge, UK, 2002.

26. Andersson, M.; Lööf, H. Agglomeration and productivity: Evidence from firm-level data. Ann. Reg. Sci. 2011, 46, 601-620. [CrossRef]

27. Zhu, S.; He, C. Global and local governance, industrial and geographical dynamics: A tale of two clusters. Environ. Plan. C Govern. Policy 2016, 34, 1453-1473. [CrossRef]

28. Van Rooij, B.; Lo, C.W. Fragile convergence: Understanding variation in the enforcement of china's industrial pollution law. Law Policy 2010, 32, 14-37. [CrossRef]

29. Rosenthal, S.S.; Strange, W.C. Geography, Industrial Organization, and Agglomeration. Rev. Econ. Stat. 2003, 85, 377-393. [CrossRef]

30. Audretsch, D.; Feldman, M. Knowledge spillovers and the geography of innovation. In Handbook of Urban and Regional Economics; Henderson, J.V., Thisse, J., Eds.; Elsevier: Amsterdam, The Netherlands, 2004; pp. 2713-2739.

31. Lin, J.; Yu, Z.; Wei, Y.D.; Wang, M. Internet access, spillover and regional development in china. Sustainability 2017, 9, 946. [CrossRef]

32. Audretsch, D.B.; Feldman, M.P. R\&d spillovers and the geography of innovation and production. Source Am. Econ. Rev. 1996, 86, 630-640.

33. Baptista, R. Do innovations diffuse faster within geographical clusters? Int. J. Ind. Organ. 2000, 18, 515-535. [CrossRef]

34. Jaffe, A.B.; Trajtenberg, M.; Henderson, R. Geographic localization of knowledge spillovers as evidenced by patent citations. Q. J. Econ. 1993, 108, 577-598. [CrossRef]

35. Cole, M.A.; Elliott, R.J.; Fredriksson, P.G. Endogenous pollution havens: Does FDI influence environmental regulations? Scand. J. Econ. 2006, 108, 157-178. [CrossRef]

36. Hosoe, M.; Naito, T. Trans-boundary pollution transmission and regional agglomeration effects. Pap. Reg. Sci. 2006, 85, 99-119. [CrossRef] 
37. Triebswetter, U.; Hitchens, D. The impact of environmental regulation on competitiveness in the German manufacturing industry-A comparison with other countries of the European Union. J. Clean. Prod. 2005, 13, 733-745. [CrossRef]

38. Mani, M.; Wheeler, D. In search of pollution havens? Dirty industry in the world economy, 1960-1995. J. Environ. Dev. 1998, 7, 215-247. [CrossRef]

39. Costantini, V.; Mazzanti, M.; Montini, A. Environmental performance, innovation and spillovers. Evidence from a regional NAMEA. Ecol. Econ. 2013, 89, 101-114. [CrossRef]

40. Greenstone, M. The Impacts of Environmental Regulations on Industrial Activity: Evidence from the 1970 and 1977 Clean Air Act Amendments and the Census of Manufactures. J. Polit. Econ. 2002, 110, 1175-1219. [CrossRef]

41. Smil, V. China's energy and resource uses: Continuity and change. China Q. 1998, 156, 935-951. [CrossRef]

42. Wu, J.; Wei, Y.D.; Chen, W.; Yuan, F. Environmental regulations and redistribution of polluting industries in transitional China: Understanding regional and industrial differences. J. Clean. Prod. 2019, 206, 142-155. [CrossRef]

43. Smil, V. China's environment and security: Simple myths and complex realities. SAIS Rev. 1997, $17,107$. [CrossRef]

44. Jahiel, A. The contradictory impact of reform on environmental protection in China. China Q. 1997, 149, 81-103. [CrossRef]

45. Yang, X.; He, C. Do polluting plants locate in the borders of jurisdictions? Evidence from China. Habitat Int. 2015, 50, 140-148. [CrossRef]

46. Cole, M.A. Trade, the pollution haven hypothesis and environmental kuznets curve: Examining the linkages. Ecol. Econ. 2004, 48, 71-81. [CrossRef]

47. Eskeland, G.S.; Harrison, A.E. Moving to greener pastures? Multinationals and the pollution haven hypothesis. J. Dev. Econ. 2003, 70, 1-23. [CrossRef]

48. Grossman, G.M.; Krueger, A.B. Environmental Impacts of a North American Free Trade Agreement; NBER Working Paper No. 3914; National Bureau of Economic Research: Boston, MA, USA, 1991.

49. Wagner, U.J.; Timmins, C.D. Agglomeration effects in foreign direct investment and the pollution haven hypothesis. Environ. Resour. Econ. 2009, 43, 231-256. [CrossRef]

50. Tsoutsos, T.; Frantzeskaki, N.; Gekas, V. Environmental impacts from the solar energy technologies. Energy Policy 2005, 33, 289-296. [CrossRef]

51. Melville, N.P. Information systems innovation for environmental sustainability. MIS Q. 2010, 34, 1-21. [CrossRef]

52. Horbach, J.; Rammer, C.; Rennings, K. Determinants of eco-innovations by type of environmental impact-The role of regulatory push/pull, technology push and market pull. Ecol. Econ. 2012, 78, 112-122. [CrossRef]

53. Hilty, L.M.; Arnfalk, P.; Erdmann, L.; Goodman, J.; Lehmann, M.; Wäger, P.A. The relevance of information and communication technologies for environmental sustainability-A prospective simulation study. Environ. Model. Softw. 2006, 21, 1618-1629. [CrossRef]

54. Wang, Y.; Kang, L.; Wu, X.; Xiao, Y. Estimating the environmental Kuznets curve for ecological footprint at the global level: A spatial econometric approach. Ecol. Indic. 2013, 34, 15-21. [CrossRef]

55. Barrios, S.; Bertinelli, L.; Strobl, E. Coagglomeration and spillovers. Reg. Sci. Urban Econ. 2006, 36, 467-481. [CrossRef]

56. Chen, X.; Shao, S.; Tian, Z.; Xie, Z.; Yin, P. Impacts of air pollution and its spatial spillover effect on public health based on China's big data sample. J. Clean. Prod. 2017, 142, 915-925. [CrossRef]

57. Gao, Q.; Abel, F.; Houben, G.; Yu, Y. A Comparative Study of Users' Microblogging Behavior on Sina Weibo and Twitter; Springer: Berlin/Heidelberg, Germany, 2012; pp. 88-101.

58. Cheng, J.; Dai, S.; Ye, X. Spatiotemporal heterogeneity of industrial pollution in China. China Econ. Rev. 2016, 40, 179-191. [CrossRef]

59. Dong, B.; Gong, J.; Zhao, X. FDI and environmental regulation: Pollution haven or a race to the top? J. Regul. Econ. 2012, 41, 216-237. [CrossRef]

60. Ciccone, A. Agglomeration effects in Europe. Eur. Econ. Rev. 2002, 46, 213-227. [CrossRef]

61. Zhou, Y.; Zhu, S.; He, C. How do environmental regulations affect industrial dynamics? Evidence from China's pollution-intensive industries. Habitat Int. 2017, 60, 10-18. [CrossRef] 
62. Balland, P.; Boschma, R.; Frenken, K. Proximity and innovation: From statics to dynamics. Reg. Stud. 2015, 49, 907-920. [CrossRef]

63. Beer, C.; Riedl, A. Modelling spatial externalities in panel data: The spatial Durbin model revisited. Pap. Reg. Sci. 2012, 91, 299-318. [CrossRef]

64. Elhorst, J.P.; Fréret, S. Evidence of political yardstick competition in France using a two-regime spatial Durbin model with fixed effects. J. Reg. Sci. 2009, 49, 931-951. [CrossRef]

65. Wu, J.; Wei, Y.; Li, Q.; Yuan, F. Economic transition and changing location of manufacturing industry in china: A study of the yangtze river delta. Sustainability 2018, 10, 2624. [CrossRef]

66. Chong, Z.; Qin, C.; Ye, X. Environmental regulation, economic network and sustainable growth of urban agglomerations in china. Sustainability 2016, 8, 467. [CrossRef]

67. Cole, M.A.; Elliott, R.J.R.; Okubo, T. Trade, environmental regulations and industrial mobility: An industry-level study of Japan. Ecol. Econ. 2010, 69, 1995-2002. [CrossRef]

68. Chang, Y.; Ries, R.J.; Wang, Y. The embodied energy and environmental emissions of construction projects in China: An economic input-output LCA model. Energy Policy 2010, 38, 6597-6603. [CrossRef]

69. Wang, C.; Du, X.; Liu, Y. Measuring spatial spillover effects of industrial emissions: A method and case study in Anhui province, China. J. Clean. Prod. 2017, 141, 1240-1248. [CrossRef]

70. Markusen, J.R.; Morey, E.R.; Olewiler, N. Competition in regional environmental policies when plant locations are endogenous. J. Public Econ. 1995, 56, 55-77. [CrossRef]

(C) 2019 by the authors. Licensee MDPI, Basel, Switzerland. This article is an open access article distributed under the terms and conditions of the Creative Commons Attribution (CC BY) license (http://creativecommons.org/licenses/by/4.0/). 